\title{
SINTESIS TALK DARI BATUAN DOLOMIT DAN KUARSA LOKAL SERTA PROSPEKNYA UNTUK INDUSTRI KIMIA DAN FARMASI
}

\section{(SYNTHESIS OF TALC FROM LOCAL DOLOMITE AND QUARTZ AND ITS PROSPECTS FOR COSMETICS AND PHARMACEUTICALS INDUSTRY)}

\author{
Chicha Nuraeni, Retno Yunilawati, dan Dwinna Rahmi \\ Balai Besar Kimia dan Kemasan. Kementerian Perindustrian. \\ JI. Balai Kimia No.1 Pekayon. Pasar Rebo. Jakarta Timur \\ E-mail : chicha.nuraeni@kemenperin.go.id
}

Received: 15 Juli 2016; revised: 17 Agustus 2016; accepted: 31 Agustus 2016;

\begin{abstract}
ABSTRAK
Talk dari bahan baku lokal berpotensi untuk dikembangkan. Telah dilakukan sintesis talk dari bahan baku lokal dolomit dan kuarsa dengan metode pemanasan/kalsinasi dan hidrotermal. Karakterisasi dolomit yang diperoleh dari Gresik, Jawa Timur menunjukkan kandungan $\mathrm{CaMg}(\mathrm{CO})_{3}$ sebanyak 71,0 \%berat dan $\mathrm{CaCO}_{3}$ sebanyak 29,0 \% berat. Pemanasan dolomit pada $300^{\circ} \mathrm{C}$ selama 24 jam menghasilkan kalsit $\mathrm{CaCO}_{3}$, periclase $\mathrm{MgO}$ dan portlandite $\mathrm{Ca}(\mathrm{OH})_{2}$, sedangkan pemanasan pada $750^{\circ} \mathrm{C}$ selama 24 jam menghasilkan kalsit $\left(\mathrm{CaCO}_{3}\right.$ dan $\mathrm{CCa}_{0.936} \mathrm{Mg}_{0.064} \mathrm{O}_{3}$ ), periclase $\mathrm{MgO}$ dan portlandite $\mathrm{Ca}(\mathrm{OH})_{2}$. Kandungan $\mathrm{MgO}$ dari pemanasan dolomit pada $300^{\circ} \mathrm{C}$ lebih tinggi daripada pemanasan $750^{\circ} \mathrm{C}$ sehingga disarankan sintesis talk dilakukan pada suhu $300^{\circ} \mathrm{C}$. Proses pengadukan bahan baku secara konvensional dan sonikasi tidak menghasilkan perbedaan produk. Proses hidrotermal selama 6 jam menghasilkan lebih banyak mineral $\mathrm{Ca}_{x} \mathrm{Mg}_{\mathrm{y}}\left(\mathrm{SiO}_{3}\right)_{2}$ dibandingkan durasi proses 12 jam dan 18 jam.
\end{abstract}

Kata kunci : Dolomit, Kuarsa, Talk, Proses hidrotermal

\begin{abstract}
Synthesis of talc from local resources is potential to be developed. In this study, synthesis of talc from local dolomite and quartz has been conducted using calcination and hidrothemal method. Characterization of dolomite, which is obtained from Gresik-East Java, shows the content of $\mathrm{CaMg}(\mathrm{CO})_{3}$ as much as $71,0 \% \mathrm{w} / \mathrm{w}$ dan $\mathrm{CaCO}_{3} 29,0 \% \mathrm{w} / \mathrm{w}$. Calcination of dolomite at $300^{\circ} \mathrm{C}$ for 24 hours produced calcite $\mathrm{CaCO}_{3}$, periclase $\mathrm{MgO}$ dan portlandite $\mathrm{Ca}(\mathrm{OH})_{2}$, while the calcination at $750^{\circ} \mathrm{C}$ produced calcite $\mathrm{CaCO}_{3}$ and calcite $\mathrm{CCa}_{0.936} \mathrm{Mg}_{0.064} \mathrm{O}_{3}$, periclase $\mathrm{MgO}$ and portlandite $\mathrm{Ca}(\mathrm{OH})_{2}$. Calcination of dolomite at $300^{\circ} \mathrm{C}$ produced more $\mathrm{MgO}$ than the process at $750^{\circ} \mathrm{C}$. The stirring process by convensional method and by sonication produced similar composition of product. Hydrothermal process for 6 hours produced more $\mathrm{Ca}_{x} \mathrm{Mg}_{y}\left(\mathrm{SiO}_{3}\right)_{2}$ compared with 12 hours and 18 hours process.
\end{abstract}

Keywords : Dolomite, Quartz, Talc, Hydrothermal process

\section{PENDAHULUAN}

Talk adalah magnesium silikat hidrat dengan komposisi kimia $\mathrm{Mg}_{3} \mathrm{Si}_{4} \mathrm{O}_{10}(\mathrm{OH})_{2}$ atau $\mathrm{H}_{2} \mathrm{Mg}_{3}\left(\mathrm{SiO}_{3}\right)_{4}$. Kata "talk" berasal dari bahasa arab yang menunjuk pada warna putih. Selain putih talk juga ada yang berwarna hijau, abuabu, coklat atau tidak berwarna. Talk bersifat tidak larut dalam air dan sedikit larut dalam asam mineral encer, memiliki kekerasan Mohs 1 (skala 1-10) (Jadhav et al. 2013). Umumnya talk dipakai sebagai filler dalam material komposit untuk mengurangi biaya produksi, meningkatkan sifat kimia dan fisika dan memberikan fungsi yang baru. Digunakan secara luas dalam industri seperti kertas, cat, keramik, kosmetik dan polimer (Ferrage et al. 2002).

Permintaan talk untuk kosmetik meningkat seiring dengan meningkatnya pertumbuhan industri kosmetik Indonesia yang mencapai 15\% di akhir tahun 2015 (Kementerian Perindustrian 2016). Akan tetapi ketersediaan talk Indonesia masih tergantung impor. China merupakan eksportir talk terbesar untuk Indonesia selama kurun waktu tahun 2010 sampai 2014 yaitu sebanyak 437 ribu ton dengan nilai \$79 juta, 
diikuti oleh India sebanyak 41 ribu ton dengan nilai $\$ 12$ juta. Meskipun pada tahun 2014 dan 2015 terjadi penurunan impor talk (Gambar 1) (UN Comtrade 2016). Selain itu, kenaikan harga talk tiap tahun (Gambar 2) menjadi masalah bagi industri kosmetik lokal, sehingga diharapkan adanya alternatif talk dengan bahan baku lokal.

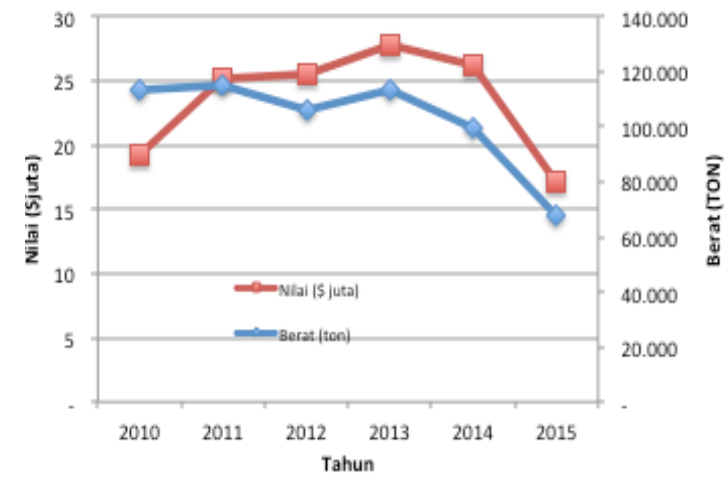

Gambar 1. Import talk Indonesia (HS Code $=252620)$ (diolah dari data UN Comtrade)

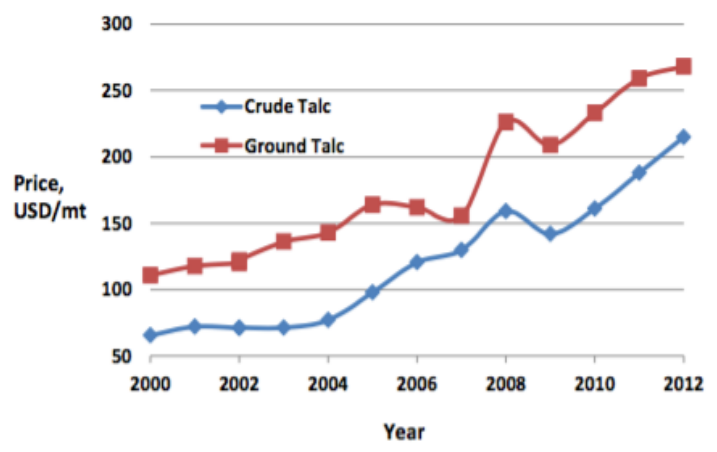

Gambar 2. Trend kenaikan harga talk (Zhuang 2013)

Berdasarkan sumbernya, talk dibedakan menjadi 2 macam yakni talk alami dan talk sintetik. Talk alami terbentuk dari transformasi batu-batuan kerak bumi oleh aksi larutan hidrotermal. Kualitas endapan talk bergantung pada sifat alamiah batuan induk dan kondisi pembentukan seperti suhu, tekanan, durasi dan sifat larutan hidrotermal sehingga tidak dapat dihancurkan secara homogen di bawah $1 \mu \mathrm{m}$ tanpa amorfisasi (Dumas et al. 2013). Oleh karena itu talk sintetik diperlukan untuk menjamin spesifikasi talk sesuai dengan yang dibutuhkan (Jadhav et al. 2013).

Dilihat dari hasil tambangnya, Indonesia mempunyai peluang sebagai penghasil talk untuk kebutuhan industri dalam negeri. Indonesia kaya akan kandungan mineral yang berpotensi untuk disintesis menjadi talk yaitu kuarsa dengan kadar silika yang tinggi dan dolomit yang kaya akan magnesium.

Sintesis talk menggunakan bahan seperti heksahidrat magnesium klorida $\left(\mathrm{MgCl}_{2} \cdot 6 \mathrm{H}_{2} \mathrm{O}\right)$ dan pentahidrat natrium metasilikat $\left(\mathrm{Na}_{2} \mathrm{SiO}_{3} .5 \mathrm{H}_{2} \mathrm{O}\right)$ telah dilakukan oleh Le Roux et al. (2012) dan Dumas et al. (2013), namun bahan tersebut kurang ekonomis dibandingkan menggunakan mineral alam jika diproduksi skala industri. Oleh karena itu, dalam penelitian ini, mineral lokal dolomit dan silika dijadikan bahan baku mensintesis talk.

\section{BAHAN DAN METODE}

\section{Bahan}

Bahan utama yang digunakan adalah dolomit dan kuarsa. Dolomit diperoleh dari daerah Gresik, Jawa Timur dan kuarsa diperoleh dari Riausilip, Kabupaten Bangka, Kepulauan Bangka Belitung. Bahan pendukung menggunakan asam asetat teknis $1 \mathrm{M}$, natrium asetat anhidrat dari Merck dan aquades.

Alat yang digunakan dalam proses sintesis adalah alat-alat gelas, tanur, reaktor tertutup "PPI" (Pressure Products Industries). Perangkat Maxima_X XRD-7000 "Shimadzu" dengan radiasi CuKa digunakan untuk mengukur kandungan mineral yang ada dalam sampel. Perangkat lunak Match! versi 1.10 digunakan untuk mencocokkan puncak difraksi eksperimen dan model.

\section{Metode}

Batuan kuarsa digunakan tanpa perlakuan awal karena kemurnian $\mathrm{SiO}_{2}$ sudah mendekati $100 \%$, sedangkan dolomit dilakukan pemanasan untuk memisahkan magnesium dari ikatan dengan bahan lain. Pemanasan dilakukan dengan 2 variabel yakni suhu $300{ }^{\circ} \mathrm{C}$ dan $750{ }^{\circ} \mathrm{C}$ selama 24 jam.

Metode sintesis dimodifikasi dari penelitian Dumas et al. (2013). Modifikasi metode diperlukan karena adanya perbedaan bahan baku dari penelitian Dumas. Tiga (3) variabel metode pengadukan dilakukan pada penelitian ini yaitu konvensional, sonikasi selama 15 menit dan reaktor tertutup. Sebanyak $3 \mathrm{~mol}$ dolomit ditambahkan dengan 4 mol kuarsa dan natrium asetat $1 \mathrm{M}$ kemudian dicampur. Setelah itu pada metoda konvensional dan sonikasi ditambahkan asam asetat teknis $1 \mathrm{M}$ dan didiamkan sampai terbentuk endapan. Endapan yang dihasilkan dicuci sebanyak 3 kali, diuapkan dan dipanaskan dalam furnace pada suhu $300{ }^{\circ} \mathrm{C}$ selama 6 jam. Dengan komposisi yang sama semua bahan dimasukkan ke dalam reaktor tertutup. Reaktor di-set pada suhu $300{ }^{\circ} \mathrm{C}$ dan sampel diambil tiap 6 jam selama 18 jam. 
Masing-masing sampel selanjutnya dikarakterisasi dengan $X$-Ray Diffraction (XRD).

Kemudian difraksi hasil analisa dibandingkan kecocokannya dengan metode kristalografi. Metode ini menggunakan perangkat lunak Match! versi 1.10 dengan cara pencocokan puncak difraksi eksperimen dan model. Analisa menggunakan perangkat lunak Match! telah banyak dilakukan untuk menentukan secara kualitatif maupun kuantitatif kandungan suatu mineral berdasarkan kecocokan puncak-puncak pola difraksi dengan database (Nong et al. 2012, Singh and Agrawal 2012)

\section{HASIL DAN PEMBAHASAN}

\section{Karakterisasi Kuarsa dan Dolomit Lokal}

Dari pola difraksi kuarsa (Gambar 3) dapat diketahui kandungan $\mathrm{SiO}_{2}$ sebesar $100 \%$ dengan berat jenis $2,651 \mathrm{~g} / \mathrm{cm}^{3}$ dengan struktur kristal trigonal (hexagonal axes), $a=4.9115 \AA$, $c=5.4038 \AA$. Karena diidentifikasi pengotornya sangat kecil, maka pada kuarsa tidak dilakukan pemanasan awal.

Pola difraksi dolomit berdasarkan hasil analisa dengan XRD ditampilkan dalam Gambar 4. Berdasarkan hasil analisa kualitatif dolomit tersebut dapat diketahui bahwa perlakuan pemanasan pada dolomit berpengaruh terhadap hasil karakterisasi komposisi bahan baku. Hasil karakterisasi dolomit awal (tanpa pemanasan) menunjukkan bahwa bahan baku dolomit memiliki pengotor $\mathrm{CaCO}_{3}$ sebanyak 29,0 \%berat (Tabel 1). Pemanasan pada $300{ }^{\circ} \mathrm{C}$ selama 24 jam menyebabkan bahan baku dolomit terpecah menjadi $\mathrm{CaCO}_{3}, \mathrm{MgO}$ dan $\mathrm{Ca}(\mathrm{OH})_{2}$. Konsentrasi $\mathrm{CaCO}_{3}$ mengalami peningkatan $5 \%$ dibanding dolomit asal dikarenakan unsur $\mathrm{Ca}$ dari dolomit $\mathrm{CaMg}(\mathrm{CO})_{3}$ terpecah membentuk senyawa $\mathrm{CaCO}_{3}$ dan $\mathrm{MgO}$. Pemanasan dolomit pada suhu $750{ }^{\circ} \mathrm{C}$ selama 24 jam menghasilkan periclase $\mathrm{MgO}$, kalsit $\left(\mathrm{CaCO}_{3}\right.$ dan $\left.\mathrm{CCa}_{0.936} \mathrm{Mg}_{0.064} \mathrm{O}_{3}\right)$, serta portlandite $\mathrm{Ca}(\mathrm{OH})_{2}$. Konsentrasi MgO mengalami penurunan dibandingkan perlakuan pemanasan pada $300^{\circ} \mathrm{C}$. Hal ini disebabkan karena sebagian magnesium berikatan dengan kalsium membentuk kristal kalsit baru yakni $\mathrm{CCa}_{0.936} \mathrm{Mg}_{0.064} \mathrm{O}_{3}$ (Tabel 1). Dari hasil ini dapat disimpulkan bahwa dalam sintesis talk menggunakan bahan baku dolomit dan kuarsa, pemanasan pada suhu $300{ }^{\circ} \mathrm{C}$ lebih baik daripada pemanasan pada $750{ }^{\circ} \mathrm{C}$ dikarenakan $\mathrm{MgO}$ yang terbentuk lebih banyak hal ini disebabkan $\mathrm{Mg}$ merupakan unsur pembentuk talk $\mathrm{Mg}_{3} \mathrm{Si}_{4} \mathrm{O}_{10}(\mathrm{OH})_{2}$.

Tabel 1. Struktur kristal batuan dolomit

\begin{tabular}{|c|c|c|c|}
\hline Sampel & \multicolumn{2}{|c|}{ Senyawa } & $\begin{array}{l}\text { Kuantitas } \\
\text { (\%berat) }\end{array}$ \\
\hline \multirow{2}{*}{$\begin{array}{l}\text { Dolomit (tanpa } \\
\text { pemanasan) }\end{array}$} & Dolomit & $\mathrm{CaMgCO}_{3}$ & 71,0 \\
\hline & Kalsit & $\mathrm{CaCO}_{3}$ & 29,0 \\
\hline \multirow{3}{*}{$\begin{array}{l}\text { Dolomit } \\
\text { (pemanasan } \\
300^{\circ} \mathrm{C} \text { ) }\end{array}$} & Kalsit & $\mathrm{CaCO}_{3}$ & 62,2 \\
\hline & Periclase & $\mathrm{MgO}$ & 21,0 \\
\hline & Portlandite & $\mathrm{Ca}(\mathrm{OH})_{2}$ & 16,8 \\
\hline \multirow{4}{*}{$\begin{array}{l}\text { Dolomit } \\
\text { (pemanasan } \\
750^{\circ} \mathrm{C} \text { ) }\end{array}$} & Kalsit & $\begin{array}{l}\mathrm{Ca}_{0.936} \mathrm{Mg}_{0.064} \\
\mathrm{CO}_{3}\end{array}$ & 46,5 \\
\hline & Kalsit & $\mathrm{CaCO}_{3}$ & 24,7 \\
\hline & Periclase & $\mathrm{MgO}$ & 16,8 \\
\hline & Portlandite & $\mathrm{Ca}(\mathrm{OH})_{2}$ & 12,00 \\
\hline
\end{tabular}

\section{Karakterisasi Talk Hasil Sintesis Dengan Pemanasan}

Talk sintetis yang dihasilkan merupakan hasil reaksi dolomit dan kuarsa. Secara garis besar reaksi dolomit dengan kuarsa tersebut dapat dituliskan sebagai berikut:

$$
\begin{array}{r}
3 \mathrm{CaMg}\left(\mathrm{CO}_{3}\right)_{2}+4 \mathrm{SiO}_{2}+\mathrm{H}_{2} \mathrm{O} \leftrightarrow \mathrm{Mg}_{3} \mathrm{Si}_{4} \mathrm{O}_{10}(\mathrm{OH})_{2} \\
+3 \mathrm{CaCO}_{3}+3 \mathrm{CO}_{2}
\end{array}
$$

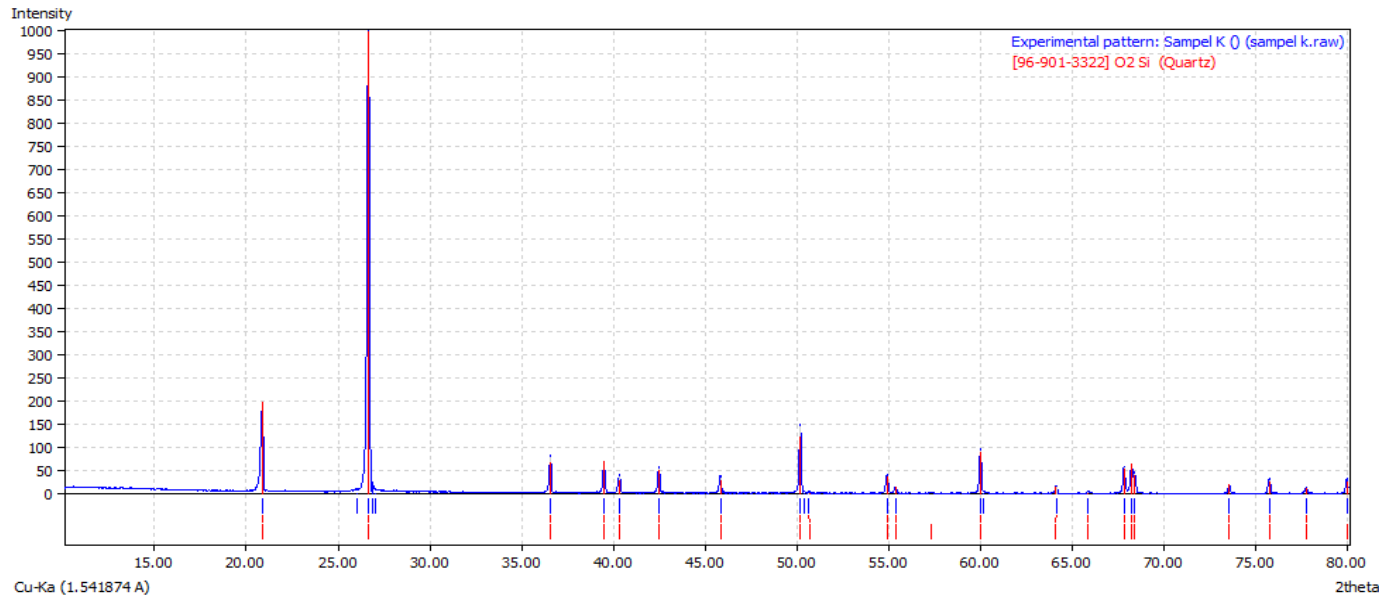

Gambar 3. Pola difraksi kuarsa 


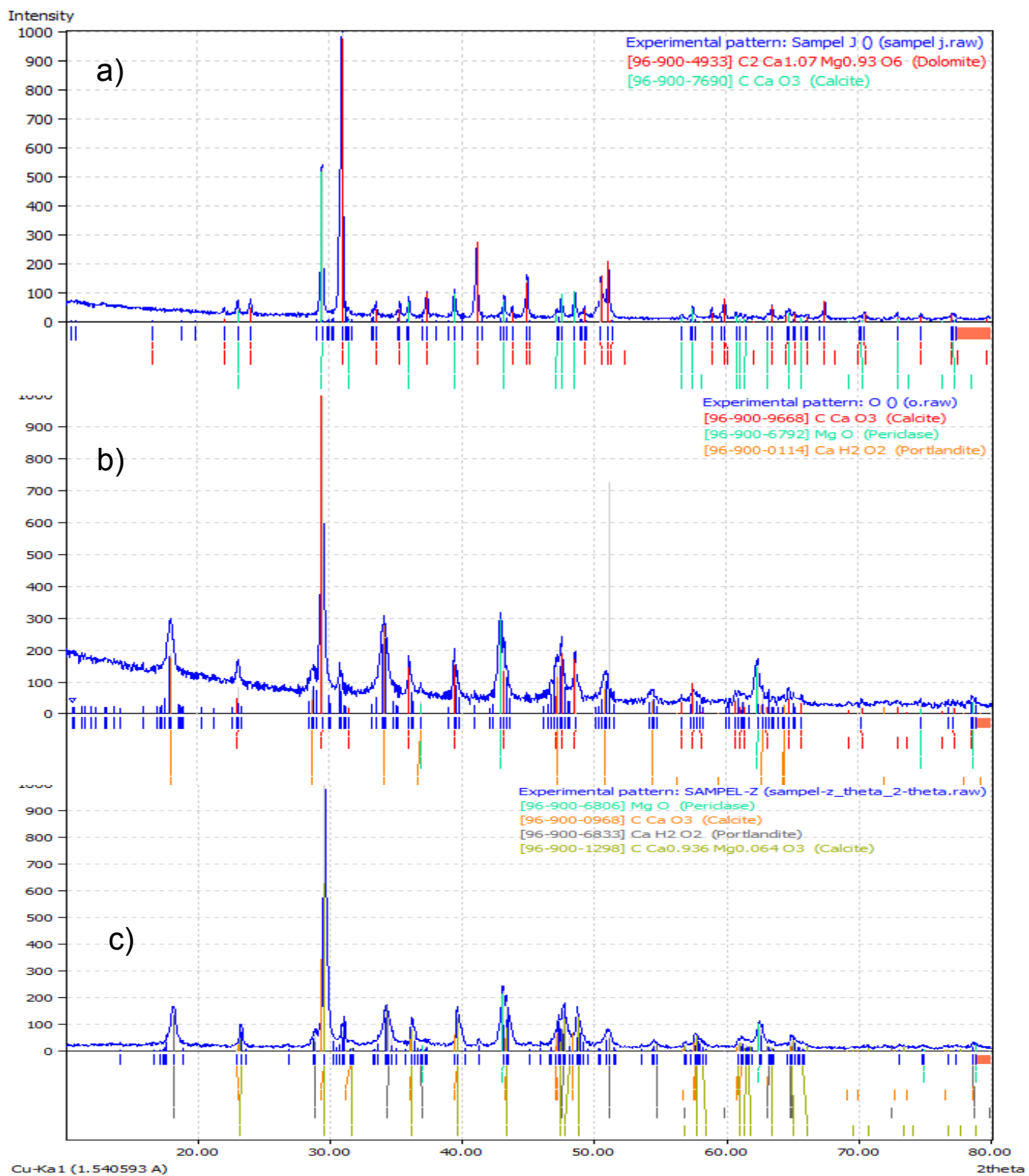

Gambar 4. Pola difraksi dolomit; a) tanpa pemanasan, b) dipanaskan $300^{\circ} \mathrm{C}$, c) dipanaskan $750^{\circ} \mathrm{C}$ selama 24 jam.

Pola difraksi talk hasil sintesis dengan pengadukan secara konvensional dan sonikasi ditampilkan pada Gambar 5. Terlihat bahwa kedua pola ini tidak berbeda signifikan. Pola difraksi ini masih menunjukkan paduan difraksi kuarsa dan dolomit.

Menurut Dumas et al. (2013), pada dasarnya semua talk sintetis terdiri atas 2 tahap preparasi yakni preparasi prekursor pada suhu ruang dan perlakuan hidrotermal. Suhu sintesis $300{ }^{\circ} \mathrm{C}$ dan waktu reaksi selama 6 jam dimaksudkan untuk menjamin kristalinitas yang seragam, tanpa penambahan tekanan, tanpa modifikasi $\mathrm{pH}$ dan konsentrasi garam natrium asetat rendah. Penambahan natrium asetat dimaksudkan untuk mempercepat reaksi pembentukan talk. Pengaruh penambahan natrium asetat pada metode ini belum dapat mempengaruhi reaksi agar terbentuk talk.

Asam asetat ditambahkan pada larutan dolomit, kuarsa dan air sebelum perlakuan hidrotermal (pemanasan dalam kondisi basah) dimaksudkan untuk kopresipitasi mineral magnesium dan silika. Menurut Cavani, Trifirò, and Vaccari (1991), dalam kopresipitasi dua atau lebih kation diperlukan pengendapan dalam kondisi jenuh, umumnya kondisi jenuh dapat tercapai dengan metode fisik (penguapan) atau kimia (variasi $\mathrm{pH}$ ). 


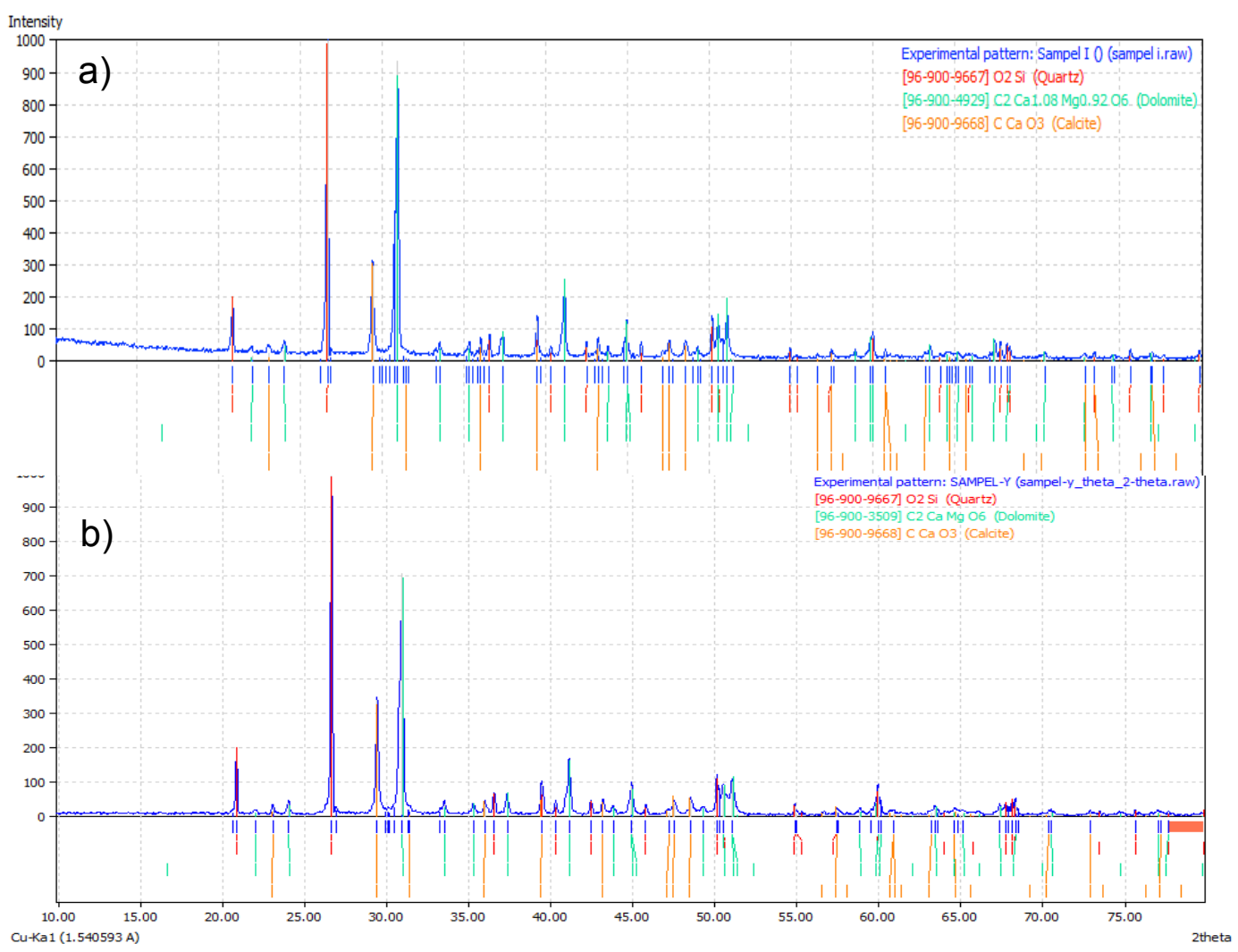

Gambar 5. Pola difraksi talk dari dolomit dan kuarsa dengan pengadukan; a. konvensional, b. sonikasi

Dalam penelitian ini kopresipitasi dilakukan secara kimia dengan variasi $\mathrm{pH}$. Sebelum penambahan asam asetat, $\mathrm{pH}$ menunjukkan angka 9 dan pada $\mathrm{pH} 8$ mulai terjadi pengendapan. Tahapan ini sekaligus untuk menyiapkan prekursor sehingga pada tahap hidrotermal laju nukleasi akan lebih tinggi daripada laju pertumbuhan kristal. Dengan tingginya laju nukleasi maka diharapkan akan terbentuk produk serbuk dengan diameter partikel yang kecil dan tidak keras.

Proses pengadukan mempengaruhi kecepatan reaksi. Pada penelitian ini, endapan yang terbentuk dengan proses sonikasi lebih cepat dibanding secara konvensional. Hal ini juga dibuktikan oleh Park et al. (2001) pada proses hidrotermal dalam pembuatan zeolit dari kaolin yaitu proses sonikasi dapat menggantikan proses hidrotermal.

\section{Karakterisasi talk hasil sintesis dengan hidrotermal}

Proses hidrotermal bertujuan untuk mensintesis talk dan mentransformasi kristalkristal kecil talk menjadi ukuran yang lebih besar. (Cavani, et al. 1991). Menurut (Byrappa and Yoshimura 2001), proses hidrotermal adalah reaksi kimia homogen ataupun heterogen dengan adanya pelarut (baik encer atapun pekat) di atas suhu ruangan dan pada tekanan di atas $1 \mathrm{~atm}$ pada sistem tertutup.

Tabel 2. Struktur kristal talk hasil proses hidrotermal

\begin{tabular}{cllc}
\hline Sampel & \multicolumn{2}{c}{ Senyawa } & $\begin{array}{c}\text { Kuantitas } \\
\text { (\%)erat) }\end{array}$ \\
\hline \multirow{2}{*}{6 jam } & Dolomit & $\mathrm{Ca}_{0.5} \mathrm{Mg}_{0.5}(\mathrm{CO})_{3}$ & 49,81 \\
\cline { 2 - 4 } & Pigeonite & $\mathrm{Ca}_{0.15} \mathrm{Mg}_{1.85}\left(\mathrm{SiO}_{3}\right)_{2}$ & 34,14 \\
\cline { 2 - 4 } & Enstatite & $\mathrm{Ca}_{0.2} \mathrm{Mg}_{1.8}\left(\mathrm{SiO}_{3}\right)_{2}$ & 16,05 \\
\hline \multirow{2}{*}{12 jam } & Dolomite & $\mathrm{Ca}_{0.5} \mathrm{Mg}_{0.5}\left(\mathrm{CO}_{3}\right.$ & 53,36 \\
\cline { 2 - 4 } & Enstatite & $\mathrm{Ca}_{0.23} \mathrm{Mg}_{1.77}\left(\mathrm{SiO}_{3}\right)_{2}$ & 46,64 \\
\hline \multirow{2}{*}{18 jam } & Quartz & $\mathrm{SiO}_{2}$ & 31,73 \\
\cline { 2 - 4 } & Dolomite & $\left.\mathrm{CaMg}_{2} \mathrm{CO}_{3}\right)_{2}$ & 41,71 \\
\cline { 2 - 4 } & Clinoenstatite & $\mathrm{Ca}_{0.15} \mathrm{Mg}_{1.85}\left(\mathrm{SiO}_{3}\right)_{2}$ & 26,56 \\
\hline
\end{tabular}

Pada penelitian ini proses hidrotermal dilakukan dalam reaktor tertutup. Dari hasil karakterisasi produk sintesis yang dihasilkan (Tabel 2) dan berdasarkan pola difraksi (Gambar 6 ), proses hidrotermal 6 jam menghasilkan senyawa $\mathrm{Ca}_{\mathrm{x}} \mathrm{Mg}_{\mathrm{y}}\left(\mathrm{SiO}_{3}\right)_{2}$ yakni berupa pigeonite dan enstatite sebanyak $50,19 \%$, sedangkan proses selama 12 jam dan 18 jam menghasilkan senyawa $\mathrm{Ca}_{\mathrm{x}} \mathrm{Mg}_{\mathrm{y}}\left(\mathrm{SiO}_{3}\right)_{2}$ masing-masing hanya $46,64 \%$ dan $26,56 \%$. Senyawa-senyawa ini mengindikasikan bahwa sudah terjadi ikatan silika dengan magnesium sebagai pembentuk talk. Kandungan terbesar adalah pada proses yang dilakukan selama 6 jam yaitu terbentuknya pigeonite dan enstatile yang masing-masing 
$34,145 \%$ dan 16,05\%. Kandungan MgSi semakin kecil ketika proses diteruskan lebih lama. Hal ini kemungkinan disebabkan karena proses terjadi pada kondisi bahan sudah mengering sehingga yang terjadi hanya pemanasan. Seperti yang diterangkan di atas pemanasan pada mineral dapat menguraikan setiap elemen yang terikat satu sama lain.

\section{Prospek Sintesis, Aplikasi dan Resiko}

Sintesis talk dapat dilakukan dengan mereaksikan batuan/pasir kuarsa sebagai sumber silika dengan batuan/pasir dolomit sebagai sumber magnesium. Indonesia memiliki potensi besar penghasil kedua bahan baku tersebut.

Kandungan kuarsa tersebar dari ujung sumatra hingga ujung timur Nusa Tenggara. Dari kajian data pertambangan Tekmira ESDM (2016), daerah yang memiliki potensi pasir kuarsa: Asahan, (Sumatra Utara) potensi sumberdaya terukur sebesar 225 ribu ton, Indragiri Hulu dan Indragiri Hilir (Riau) potensi sumberdaya terukur 5,4 juta ton dan sumberdaya hipotetik sebesar 85 juta ton,Tanah Datar, Sawahlunto, dan Solok potensi sumberdaya terindikasi (780 ribu ton), sumberdaya tereka (1,3 juta ton), sumberdaya hipotetik (3,7 ribu juta ton). Pulau Bangka dan Pulau Belitung sumberdaya kuarsa terukur (59 juta ton), sumberdaya terindikasi (12 juta ton), sumberdaya tereka (10,7 juta ton), sumberdaya hipotetik (13,2 juta ton),Banten dan Sukabumi (Jawa Barat) sumberdaya terukur 5,5 juta ton, sumberdaya tereka 4,1 juta ton dan sumberdaya hipotetik 51 juta ton,

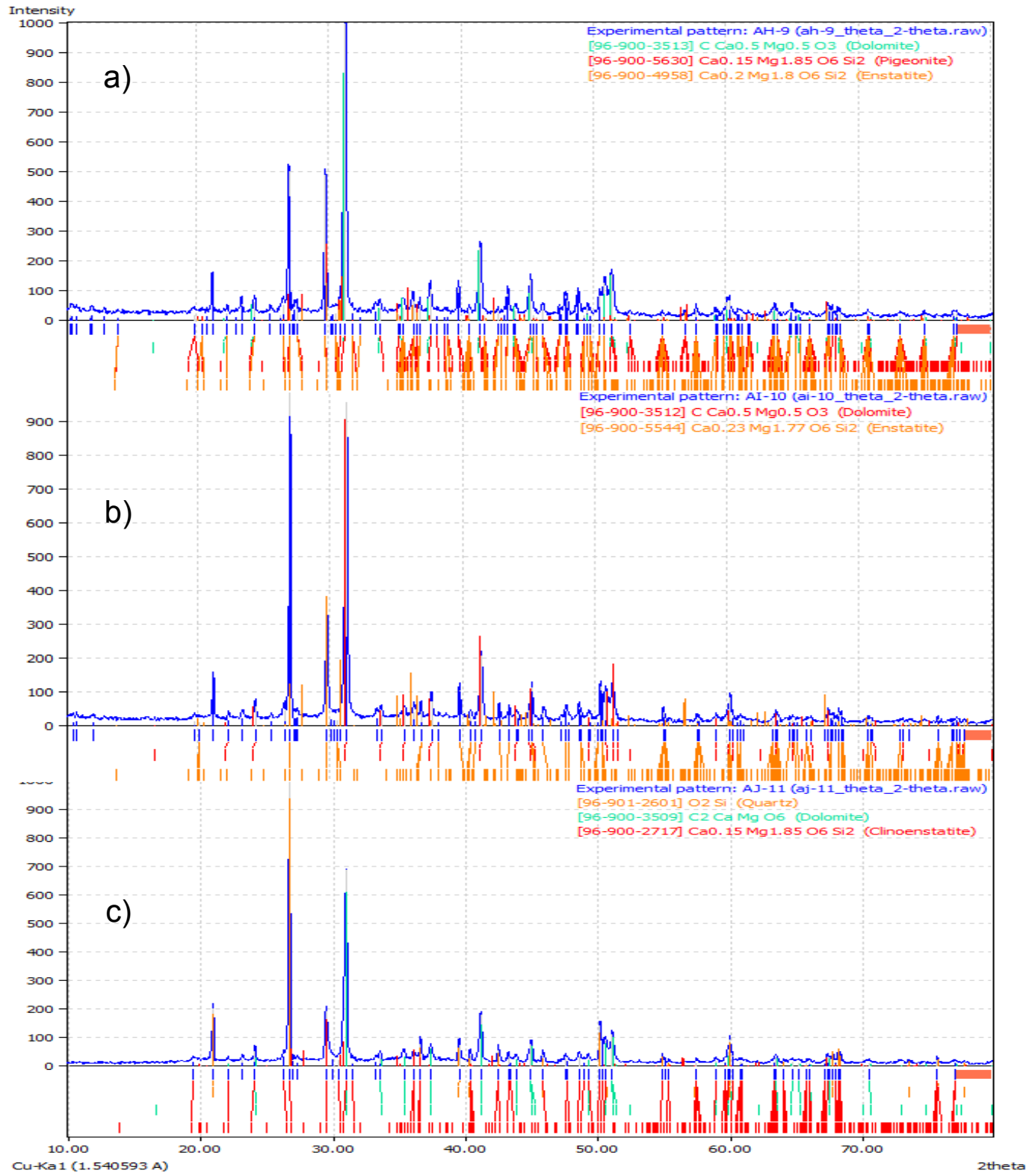

Gambar 6. Pola difraksi talk dari hasil proses hidrotermal; a) 6 jam, b) 12 jam dan c) 18 jam 
Rembang (Jawa Tengah) memiliki sumberdaya kuarsa terukur 572 ribu ton, sumberdaya hipotetik 1,4 juta ton.Tuban dan Sumenep (Jawa Timur) sumberdaya terukur 1,1 juta ton, sumberdaya terekam 886 ribu ton, dan sumberdaya hipotetik sebesar 2,7 juta ton. Sambas dan Sangau (Kalimantan Barat) sumberdaya hipotetik 330 juta ton. Banahan (Kalimantan Selatan ) sumberdaya hipotetik 49 juta ton. Kutai (Kalimantan Timur) sumberdaya terukur 810 ribu ton dan sumbedaya hipotetik 4 juta ton. Maros (Sulawesi Selatan) sumberdaya hipotetik sebesar 3,5 juta ton dan Amanatun Utara (NTT) sumberdaya hipotetik 92 juta ton.

Sementara dari kajian Tushadi (1990) magnesium dapat diperoleh dari bijih magnesium antara lain magnesit $\left(\mathrm{MgCO}_{3}\right)$, dolomit $\left(\mathrm{CaCO}_{3} \cdot \mathrm{MgCO}_{3}\right)$, dan karnalit $\left(\mathrm{MgCl}_{2} \mathrm{KCl} \cdot 6 \mathrm{H}_{2} \mathrm{O}\right)$. Penggunaan dolomit belum seluas magnesit namun dolomit lebih banyak di alam. Menurut Tushadi (1990), dolomit tersebar hampir di seluruh Indonesia dan potensi terbesar di daerah Sumatera Utara, Sumatera Barat, Jawa Tengah, Jawa Timur dan Madura serta Papua. Di Jawa Timur, diperkirakan terdapat cadangan dolomit sebanyak 430 juta ton di Socah, Bangkalan Madura; 70 juta $\mathrm{m}^{3}$ di bukit Kaklak Gresik dan 50 juta $\mathrm{m}^{3}$ di Sekapuk, Tuban (Tekmira ESDM 2016)

Dalam bidang farmasi, talk telah digunakan secara luas untuk tablet, pil dan kapsul dikarenakan sifatnya yang inert secara fisiokimia dan murah. Talk dapat berfungsi dalam berbagai eksipien seperti bahan pengisi (filler), bahan pelicin (Iubricant) dan glidan, serta dalam formulasi kosmetik sebagai bahan anticaking, abrasive, absorbent, opacifying agent, bulking agent, skin protectant dan slip modifier. (Jadhav et al. 2013)

Dalam industri kosmetik, talk merupakan komponen utama untuk bedak wajah, eye shadows, dan blushers. Bedak kosmetik harus putih, bebas asbes dan memiliki daya sebar tinggi dengan sedikit usapan. Talk secara alami bersifat oleofilik-hidrofobia sehingga membantu adesi kulit dan air (Kogel 2006). Dalam beberapa produk, talk mengisi $70 \%$ bagian dari formulasi (Elsner and Maibach 2005).

Pada talk alami, adanya pengotor dalam talk dapat beresiko ketika diaplikasikan. Pengotor umum pada talk alami adalah tremolit $\left(2 \mathrm{CaO} .5 \mathrm{MgO} .8 \mathrm{SiO}_{2} \cdot \mathrm{H}_{2} \mathrm{O}\right)$ atau asbestos yang mana tidak diperbolehkan ada dalam talk komersial.

Selain pengotor yang terkandung didalam talk pemakaian talk untuk bidang farmasi masih menjadi bahan perbincangan. Beberapa jurnal telah membahas keselamatan pemakaian talk terkait hubungannya dengan pneumonia, kanker paru-paru dan kanker ovarium. Namun, kebanyakan belum memberikan bukti yang kuat (Wehner 2002). Food and Drug Association (FDA) US memberikan aturan terkait pemakaian talk dalam formulasi kosmetik dan farmasi dikarenakan talk merupakan 1 dari 25 eksipien yang banyak digunakan dalam farmasi. Diindikasikan bahwa saat ini talk telah dipakai dalam 2000 lebih formulasi kosmetik dari 45 kategori produk kosmetik yang berbeda. Dalam Pharmacopoei EP 4th dan USP 29, talk memiliki nama "Talc", terdaftar pada nomor CAS 1480796-6 (hydrated magnesium silicate), 11119-41-8, 99638-63-8,12420-12-1, 37232-12-5, 11054041-5. Selain itu di pasar, talk juga memiliki nama lain seperti agalite, emtal, finntalc, french chalk, micron white, mistron, snowgoose, soapstone, steatite, steawhite, talcum (López et al. 2007).

Terkait pemakaian talk untuk kosmetik dan farmasi, tes khusus harus dilakukan yakni USP dan EP mention X-ray diffraction dan spektrofotometer infra merah untuk mengontrol keberadaan asbestos. Talk grade kosmetik harus memiliki kemurnian tinggi $(0.1 \%$ maksimal retensi pada ayakan IS 150 mikro) dan warna tidak boleh berubah ketika dipanaskan pada $200^{\circ} \mathrm{C}$. Derajat penghalusan bervariasi antara 200 mesh $(74 \mu \mathrm{m})$ untuk powder badan, sampai 325 mesh $(44 \mu \mathrm{m})$ untuk kosmetik dan farmasi dan 400 mesh $(37 \mu \mathrm{m})$ dan aplikasi kosmetik tertentu seperti pressed powder (Zazenski et al. 1995).

Sebagai tambahan, talk memiliki sifat kimia dan fisika yang unik meliputi sifatnya yang inert, higroskopis, self-aggregation, lubrication, tactile sensation, translucency dan warna. Sifatsifat inilah yang membuat talk lebih disukai daripada bahan lain seperti kaolin dan tepung nabati.

\section{KESIMPULAN}

Bahan baku dolomit yang diperoleh dari Gresik, Jawa Timur memiliki kandungan $\mathrm{CaMg}(\mathrm{CO})_{3}$ sebanyak $71,0 \%$ dan $\mathrm{CaCO}_{3}$ sebanyak 29,0 \%. Pemanasan dolomit pada $300^{\circ} \mathrm{C}$ selama 24 jam menghasilkan kalsit $\mathrm{CaCO}_{3}$, periclase $\mathrm{MgO}$ dan portlandite $\mathrm{Ca}(\mathrm{OH})_{2}$, sedangkan pemanasan pada $750{ }^{\circ} \mathrm{C}$ selama 24 jam menghasilkan kalsit $\left(\mathrm{CaCO}_{3}\right.$ dan $\mathrm{CCa}_{0.936}$ $\left.\mathrm{Mg}_{0.064} \mathrm{O}_{3}\right)$, periclase $\mathrm{MgO}$ dan portlandite $\mathrm{Ca}(\mathrm{OH})_{2}$. Kandungan $\mathrm{MgO}$ dari pemanasan dolomit pada $300{ }^{\circ} \mathrm{C}$ lebih tinggi daripada pemanasan $750{ }^{\circ} \mathrm{C}$ sehingga disarankan sintesis talk dilakukan pada suhu $300{ }^{\circ} \mathrm{C}$. Proses pengadukan bahan baku secara konvensional dan sonikasi tidak menghasilkan perbedaan produk. Proses hidrotermal selama 6 jam menghasilkan lebih banyak mineral $\mathrm{Ca}_{\mathrm{x}} \mathrm{Mg}_{\mathrm{y}}\left(\mathrm{SiO}_{3}\right)_{2}$ dibandingkan durasi proses 12 jam dan 18 jam. 
Pemakaian talk pada bidang kosmetik dan farmasi harus melalui uji lengkap dan disesuaikan dengan standar yang berlaku.

\section{UCAPAN TERIMA KASIH}

Penulis menyampaikan terima kasih kepada pimpinan Balai Besar Kimia Kemasan yang sudah memfasilitasi sehingga terlaksananya penelitian ini.

\section{DAFTAR PUSTAKA}

Byrappa, K., and M. Yoshimura. 2001. Handbook of Hydrothermal Technology: Elsevier Science.

Cavani, F., F. Trifirò, and A. Vaccari. 1991. Hydrotalcite-type anionic clays: Preparation, properties and applications. Catalysis today 11 (2):173-301.

Dumas, A., F. Martin, E. Ferrage, P. Micoud, C. Le Roux, and S. Petit. 2013. Synthetic talc advances: Coming closer to nature, added value, and industrial requirements. Applied Clay Science 85:8-18. doi: 10.1016/j.clay.2013.09.006.

Elsner, P., and H.I. Maibach. 2005. Cosmeceuticals and active cosmetics (drugs versus cosmetics). Cosmetic science and technology series.

Ferrage, E., F. Martin, A. Boudet, S. Petit, G. Fourty, F. Jouffret, P. Micoud, P. De Parseval, S. Salvi, C. Bourgerette, J. Ferret, Y. Saint-Gerard, S. Buratto, and J. P. Fortune. 2002. Talc as nucleating agent of polypropylene: morphology induced by lamellar particles addition and interface mineral-matrix modelization. Journal of Materials Science 37 (8):1561-1573. doi: 10.1023/a:1014929121367.

Jadhav, N.R., A.R. Paradkar, N.H. Salunkhe, R.S. Karade, and G.G. Mane. 2013. Talc: A Versatile Pharmaceutical Excipient. World Journal of Pharmacy and Pharmaceutical Sciences 2 (6):4639-4660

Kementerian Perindustrian. 2016. Industri Kosmetik Diprediksi Tumbuh 15\%. http://kemenperin.go.id/artikel/7297/Indu stri-Kosmetik-Diprediksi-Tumbuh-15.

Diakses tanggal 3 Mei 2016.

Kogel, J.E. 2006. Industrial Minerals \& Rocks: Commodities, Markets, and Uses: Society for Mining, Metallurgy, and Exploration.

Le Roux, C., F. Martin, P. Micoud, and A. Dumas. 2014. Process for preparing a composition comprising synthetic mineral particles and composition. US Patent 2014/0205528 A1

López-Galindo, A., C. Viseras, and P. Cerezo. 2007. Compositional, technical and safety specifications of clays to be used as pharmaceutical and cosmetic products. Applied Clay Science 36 (13):51-63. doi: 10.1016/ j.clay.2006.06.016.

Nong, L., X. Yang, L. Zeng, and J. Liu. 2012. Qualitative and quantitative phase analyses of Pingguo bauxite mineral using X-ray powder diffraction and the Rietveld method. Powder Diffraction 22 (4):300-302. doi: 10.1154/1.2790941.

Park, J., B. C. Kim, S. S. Park, and H. C. Park. 2001. Conventional versus ultrasonic synthesis of zeolite 4A from kaolin. Journal of Materials Science Letters 20 (6):531-533. doi: 10.1023/ a:1010976416414.

Singh, V., and H.M. Agrawal. 2012. Qualitative soil mineral analysis by EDXRF, XRD and AAS probes. Radiation Physics and Chemistry 81 (12):1796-1803.

Tekmira ESDM. 2016. www.tekmira.esdm.go.id/data/ulasan.asp. Diakses tanggal 3 Mei 2016

Tushadi. 1990. Analisa Penyebaran Dolomit di Indonesia. In Laporan Badan Penelitian dan Pengembangan Provinsi Sumatera Utara.

UN Comtrade. 2016. UN Comtrade Database, http://comtrade.un.org/data/.

Wehner, A.P. 2002. Cosmetic Talc Should Not Be Listed as a Carcinogen: Comments on NTP's Deliberations to List Talc as a Carcinogen. Regulatory Toxicology and Pharmacology 36 (1): 40-50, doi: 10.1006/ rtph.2002.1560.

Zazenski, R., W.H. Ashton, D. Briggs, M. Chudkowski, J.W. Kelse, L. MacEachern, E.F. McCarthy, M.A. Nordhauser, M. T. Roddy, and N. M Teetsel. 1995. Talc: occurrence, characterization, and consumer applications. Regulatory Toxicology and Pharmacology 21 (2):218-229.

Zhuang, J. X. 2013. Chinese Talc and its Outlook. Haichenco. China 